УДК 930 (517.3)

ББК 63 (5Mo)

DOI $10.31554 / 2222-9175-2019-36-286-290$

Э. В. Батунаев

О ГЕРОЯХ БЫАЫХ ВРЕМЕН (СТРАНИЦЫ РОССИЙСКО-МОНГОАЬСКОГО БОЕВОГО СОАРУЖЕСТВА)

Рецензия на коллективную монографию «Монголия в борьбе за независимость (1939-1945 гг.): от Халхин-гола до линкора “Миссури”». К 80-летию победы на реке Халхин-Гол / Б. В. Базаров, Ж. Базарсурэн, Л. В. Курас, В. Б. Базаров, Д. Д. Бадараев, Н. В. Барданов, Б. Ц. Жалсанов, Б. Д. Цыбенов, Х. Шагдар. - Иркутск: Оттиск, 2019. - 156 с.

E. V. Batunaev

\title{
ABOUT HEROES OF FORMER TIMES (PAGES OF THE RUSSIAN-MONGOLIAN COMBAT FRIENDSHIP)
}

A review of the monograph: "Mongolia in the fight for independence (1939-1945): from the Khalkhin Gol to the "Missuri" linkor" / B. V. Bazarov, Zh. Bazarsurjen, L. V. Kuras, V. B. Bazarov, D. D. Badaraev, N. V. Bardanov, B. C. Zhalsanova, B. D. Tsybenov, H. Shagdar. Irkutsk: Ottisk, 2019. - 156 s.

От героев быльх времен не осталось порой имен. Те, кто приняли смертный бой, стали просто землей и травой. Только грозная доблесть их поселилась в сердиах живых...

Евгений Агранович

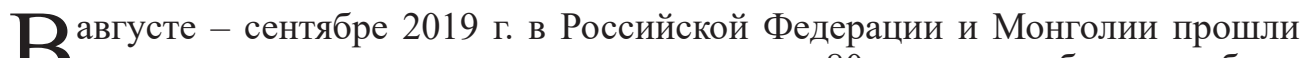
торжественные мероприятия, посвященные 80-летнему юбилею победы советско-монгольских войск на р. Халхин-Гол. События прошлых лет продолжают привлекать внимание мировой общественности, в первую очередь ученых-историков: проводятся симпозиумы, конференции и круглые столы. В сентябре 2019 г. Президент Российской Федерации В. В. Путин по приглашению монгольского главы Х. Баттулги посетил Монголию и принял участие в торжественных мероприятиях. Как отметил В. В. Путин, «Россия с благодарностью вспоминает помощь Монголии, а победа на р. Халхин-Гол является знаковым событием нашей общей истории» [Начало встречи с Президентом Монголии... 2019]. Таким образом, общая победа, доставшаяся ценой немалых потерь, продолжает играть тесную связующую роль в двусторонних отношениях.

Приграничные с Монголией российские регионы (Республика Бурятия, Забайкальский край, Иркутская область) также активно проводят торжественные мероприятия, научные конференции. Так, в мае 2019 г. в Бурятском государственном университете прошло юбилейное научное мероприятие, посвященное халхинголь-

БАТУНАЕВ Эдуард Владимирович - кандидат исторических наук, научный сотрудник Федерального государственного бюджетного учреждения науки «Институт монголоведения, буддологии и тибетологии СО РАН» (Улан-Удэ, Россия). E-mail: Batunaeveduard@mail.ru. 
ским событиям, на котором с докладами выступили сотрудники ИМБТ СО РАН: академик РАН Б. В Базаров, д.и.н., проф. Л. В. Курас; к.и.н., доц. Б. Д. Цыбенов. 23 августа 2019 г. в здании Правительства Республики Бурятия состоялась презентация историко-документальной межархивной выставки «Память и нетленная слава двух побратавшихся стран...». Организатором выставки стал Государственный архив Республики Бурятия. В мае 2019 г. в Байкальском государственном университете (г. Иркутск) прошла международная научно-практическая конференция «Победа советско-монгольских войск над японскими захватчиками у р. Халхин-Гол 1939 г. в мировой и отечественной истории». В сентябре 2019 г. в г. Чите состоялась Международная научная конференция «Приграничное сотрудничество: исторические события и современные реалии», посвященная 80-летию победы советских и монгольских войск на р. Халхин-Гол.

Исследование халхингольских событий является одним из приоритетных направлений в ИМБТ СО РАН. На протяжении многих лет ученые-историки института плодотворно изучают различные аспекты советско-монгольского военного содружества, основанные на совместном ведении боевых действий в 1939 г. в районе Халхин-Гола. В 2010 г. был издан сборник научных статей «От Халхин-Гола до линкора “Миссури”» (научные редакторы Ч. Дашдаваа, Л. В. Курас), который стал итогом успешного сотрудничества историков двух стран, проводившегося в рамках совместного научного проекта Российского научного гуманитарного фонда (РГНФ) и Министерства образования, науки и культуры Монголии [Ариунбаяр 2019]. Фотографии военных лет вкупе с обзорными научными статьями Л. В. Кураса и Н. Хишигт были представлены в работе 2011 г. «Монголия во второй мировой войне: фотоальбом», где Л. В. Курас детально рассматривает положение МНР в 40-е гг. XX в. В частности, он делает вывод, что руководство и СССР и МНР понимало временность возникшего после конфликта на р. Халхин-Гол затишья [Монголия во Второй мировой войне 2011: 3].

Особое место в ряду совместных российско-монгольских научных публикаций занимает сборник документов «Российско-монгольское военное сотрудничество от Халхин-Гола до линкора “Миссури” (1939-1946 гг.)», куда вошли ценные архивные документы, содержащиеся в федеральных государственных и ведомственных архивах России и Монголии. В основном они представлены приказами и донесениями воинских частей РККА и МНРА, также имеются и приказы японского командования [Российско-монгольское военное сотрудничество 2011]. В 2017 г. была издана монография «Монголия во Второй мировой войне (1939-1945 гг.)» под редакцией Л. В. Кураса и С. Ганболда. В этой коллективной работе российские и монгольские историки уделили внимание и событиям на Халхин-Голе. Во введении и первой главе монографии имеются разделы, посвященные российско-монгольской историографии событий на Халхин-Голе [Монголия во Второй мировой войне... 2017: 15-26].

В преддверии 80-летнего юбилея в августе 2019 г. вышла в свет коллективная монография российских и монгольских историков «Монголия в борьбе за независимость (1939-1945 гг.): от Халхин-Гола до линкора “Миссури”». Авторами исследования проделана большая работа, выразившаяся в переосмыслении и новой трактовке многих исторических событий, выявлении и детальном изучении новых источников и документов, проливающих свет на неисследованные стороны событий 1939 г. на р. Халхин-Гол, всестороннюю помощь Советскому Союзу в годы Великой Отечественной войны и участие Монголии на заключительном этапе Второй мировой войны.

Следует отметить, что настоящая монография явилась продолжением научноисследовательских работ 2010-2018 гг., которые проводились при финансовой под- 
держке РГНФ и Министерства образования, науки и культуры Монголии и получили высокую оценку научной общественности как в России, так и в Монголии.

В трех частях книги «Монголия в борьбе за независимость (1939-1945 гг.): от Халхин-Гола до линкора “Миссури”» в хронологической последовательности читателю представлен один из самых сложных и драматических периодов в истории Монголии - борьба за независимость и суверенитет, укрепление национальной государственности в тесном сотрудничестве с Россией.

В первой части книги совершен исторический экскурс в геополитику, рассмотрены причины и предпосылки, ход боевых действий вооруженного противостояния на р. Халхин-Гол. Объективные и взвешенные оценки авторов позволяют определить характер вооруженного конфликта, влияние на условия возникновения Второй мировой войны, проанализировать расстановку сил ведущих держав, проследить формирование новой системы международных отношений в регионе и мире. К важным выводам относится мнение авторов о том, что битва на Халхин-Голе стала высшей точкой восточноазиатского противостояния в предвоенные годы. Она показала несостоятельность военного формирования геополитических преимуществ в сложном механизме социально-политического взаимодействия в этом обширном регионе [Монголия в борьбе за независимость... 2019: 24].

Вторая часть монографии посвящена теме братской помощи монгольского народа, оказанной СССР в суровые годы Великой Отечественной войны 1941-1945 гг., когда Монголия, руководствуясь союзническим долгом, внесла серьезный вклад в победу СССР над фашистской Германией. Страна оказала большую материальную помощь и моральную поддержку Красной Армии и Советскому государству. На основе монгольского сборника «О фронте» (на старомонгольской письменности) авторами отражена всемерная материальная и моральная помощь монгольского народа. Необходимо отметить, что параграфы раздела включают в себя следующие пункты: прибытие делегации, встреча с командованием фронта, беседы с местными жителями и немецкими военнопленными, посещение воинских частей и вручение подарков, присутствие при начале артиллерийского обстрела противника, встреча с ранеными в полевом госпитале. При этом отмечается, что делегации МНР побывали на Волховском, Западном, Калининском, Северо-Западном, Центральном фронтах [Там же: 11].

Авторами подчеркивается, что помощь имела несколько направлений: сбор подарков, приобретение боевой техники на средства монгольского народа, продажа и дарение лошадей, индивидуальные посылки и т. д. Всего в годы войны было отправлено из МНР в СССР шесть эшелонов с подарками для советских военнослужащих. Общая безвозмездная помощь СССР составила 65770060 тугр. (86421859 руб.) [Там же: 7].

Заключительная часть посвящена Дальневосточной военной операции, непосредственному участию монгольских воинских частей в военных действиях против Японии с 27 июля по 2 августа 1945 г. Особое внимание уделено подготовке и реализации операции, заложенной еще на Крымской конференции в феврале 1945 г. Подчеркивается, что И. В. Сталин считал необходимым участие Монголии в заключительной операции Второй мировой войны, от успеха которой зависела судьба страны и ее независимость [Там же: 74].

Исследователи последовательно показывают весь ход боевых действий, основные направления маньчжурской стратегической операции советско-монгольских войск. Оценки авторов исследования усиливаются мнением о том, что была проведена большая работа по достижению взаимодействия флота и сухопутных советско-монгольских войск. Дело осложнялось тем, что наступательная операция 
осуществлялась в пустыне, горах, на реках и болотистой местности. Отмечается особый полководческий талант командира конно-механизированной группы (КМГ) генерал-полковника И. А. Плиева [Монголия в борьбе за независимость... 2019: 80]. КМГ должна была осуществить наступление на правом крыле фронта и нанести основной удар в направлении Долонура на глубине 950 км. Показана роль МНРА в наступательной операции. Отмечается, что монгольские кавалерийские дивизии прекрасно ориентировались на местности, совершали марши на 100-500 км.

Таким образом, как справедливо отмечают авторы книги, «своими идеями, размахом, интенсивностью, задачами, реализованными способами, конечными результатами маньчжурская операция, проведенная под руководством А. М. Василевского, является одной из выдающихся операций Вооруженных Сил СССР во Второй мировой войне [Монголия в борьбе за независимость... 2019: 85].

Материалы исследования логически дополняются фотографиями. В приложении впервые вводятся в научный оборот материалы «Бурят-Монгольской правды» и документы Государственного архива Республики Бурятия о погибших и пропавших без вести уроженцах Бурятии во время событий на р. Халхин-Гол. Как отметил в предисловии к монографии глава Республики Бурятия А. С. Цыденов, «весомый вклад в победу над японскими агрессорами внесли воины-забайкальцы: более 15 тысяч наших земляков стали участниками событий на реке Халхин-Гол» [Монголия в борьбе за независимость... 2019: 3].

В целом монография представляет своевременный и содержательный труд, в котором на основе монгольских, российских и других источников и литературы, новых архивных документов предпринята позитивная попытка представить истинную картину исторических предпосылок, причин и хода событий на Халхин-Голе, оказания всесторонней помощи Монголии Советскому Союзу в Великой Отечественной войне и участия Монголии в заключительном этапе Второй мировой войны. Опубликованная книга, безусловно, привлечет внимание отечественных историков, монголоведов и широкого круга читателей, интересующихся вопросами истории Монголии, российско-монгольских отношений, многолетней дружбы и сотрудничества России и Монголии.

Работа выполнена в рамках государственного задания ИМБТ СО РАН по проекту № 0338-2016-0003 «Межкультурное взаимодействие, этнические и сочиально-политические прочессы в Центральной Азии».

\section{Аитература}

Ариунбаяр Б. Президент РФ В. Путин дал интервью газете «Одрийн сонин» в преддверии своего официального визита в Монголию [Электронный ресурс] / Б. Ариунбаяр. - Режим доступа: https:/www.montsame.mn/ru/read/199437 (дата обращения: 08.09.2019).

Монголия в борьбе за независимость (1939-1945 гг.): от Халхин-Гола до линкора «Миссури». К 80-летию победы на реке Халхин-Гол / рук. проекта и науч. ред. Б. В. Базаров, Л. В. Курас; Б. В. Базаров, Ж. Базарсурэн, Л. В. Курас и др. - Иркутск: Оттиск, 2019. $156 \mathrm{c}$.

Монголия во Второй мировой войне: фотоальбом / науч. ред. Ч. Дашдаваа, Л. В. Курас. Иркутск: Оттиск, 2011. - 96 с.

Монголия во Второй мировой войне (1939-1945 гг.): кол. моногр. / рук. проекта, отв. ред. Л. В. Курас, С. Ганболд; науч. рук. Б. В. Базаров, Х. Шагдар. - Иркутск: Оттиск, 2017. $224 \mathrm{c}$.

Начало встречи с Президентом Монголии Халтмагийн Баттулгой [Электронный ресурс] // Официальное Интернет-представительство Президента России. - Режим доступа: http://www.kremlin.ru/events/president/transcripts/61430 (дата обращения: 08.09.2019). 
От Халхин-Гола до линкора «Миссури»: сб. науч. ст. / науч. ред. Ч. Дашдаваа, Л. В. Куpac. - Улан-Удэ: ИПК ФГОУ ВПО ВСГАКИ, 2010. - 141 с.

Российско-монгольское военное сотрудничество от Халхин-Гола до линкора «Миссури» (1939-946 гг.): сб. док. / науч. ред. Б. В. Базаров, Ч. Дашдаваа. - Улан-Удэ; Улан-Батор: Оттиск, 2011. - $171 \mathrm{c}$.

\section{References}

Ariunbayar B. Prezident RF V. Putin dal interv’yu gazete «Odrijn sonin» v preddverii svoego oficial'nogo vizita v Mongoliyu [Elektronnyj resurs] / B. Ariunbayar. - Rezhim dostupa: https:// www.montsame.mn/ru/read/199437 (data obrashcheniya: 08.09.2019).

Mongoliya v bor'be za nezavisimost' (1939-1945 gg.): ot Halhin-Gola do linkora «Missuri». K 80-letiyu pobedy na reke Halhin-Gol / ruk. proekta i nauch. red. B. V. Bazarov, L. V. Kuras; B. V. Bazarov, Zh. Bazarsuren, L. V. Kuras i dr. - Irkutsk: Ottisk, 2019. - 156 s.

Mongoliya vo Vtoroj mirovoj vojne: fotoal'bom / nauch. red. Ch. Dashdavaa, L. V. Kuras. Irkutsk: Ottisk, 2011. - $96 \mathrm{~s}$.

Mongoliya vo Vtoroj mirovoj vojne (1939-1945 gg.): kol. monogr. / ruk. proekta, otv. red. L. V. Kuras, S. Ganbold; nauch. ruk. B. V. Bazarov, H. Shagdar. - Irkutsk: Ottisk, 2017. - 224 s.

Nachalo vstrechi s Prezidentom Mongolii Haltmagijn Battulgoj [Elektronnyj resurs] // Oficial'noe Internet-predstavitel'stvo Prezidenta Rossii. - Rezhim dostupa: http://www.kremlin. ru/events/president/transcripts/61430 (data obrashcheniya: 08.09.2019).

Ot Halhin-Gola do linkora «Missuri»: sb. nauch. st. / nauch. red. Ch. Dashdavaa, L. V. Kuras. - Ulan-Ude: IPK FGOU VPO VSGAKI, 2010. - $141 \mathrm{~s}$.

Rossijsko-mongol'skoe voennoe sotrudnichestvo ot Halhin-Gola do linkora «Missuri» (1939-946 gg.): sb. dok. / nauch. red. B. V. Bazarov, Ch. Dashdavaa. - Ulan-Ude; Ulan-Bator: Ottisk, 2011. - $171 \mathrm{~s}$. 